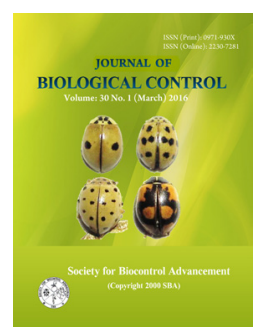

\title{
Study of predatory lady beetles fauna (Coleoptera, Coccinellidae) associated with pomegranate orchards on Aphis punicae Passerini in the Najafabad region (Isfahan province), Iran
}

\author{
ZAHRA FATTAH-ALMANAN, ALIREZA JALALI-ZAND* and BIJAN HATAMI \\ Department of Entomology, Khorasgan (Isfahan) Branch, Islamic Azad University, Isfahan, Iran \\ ${ }^{*}$ Corresponding author E-mail: arjalalizand@gmail.com
}

\begin{abstract}
Lady beetles (Coleoptera: Coccinellidae) as a biological control agent are a group of beetles with a considerable diversity and adaptation in different habitats. Among aphids, Aphis punicae Passerini (Hemiptera: Aphididae) is one of the most important pests of pomegranate orchards in Iran. This pest reduces plant vigor, facilitates the growth of mold on leaves, and consequently influences crop quality and yield. Study on the fauna of predatory ladybugs associated with pomegranate orchards was conducted that were feeding on Aphis punicae in the Najafabad region (Isfahan province, Iran). Twelve species of 8 genera were collected sampled specimens were identified according to their morphological, male and female genitalia characters using identification keys. The identified species were as follow: Adalia bipunctata (Linnaeus, 1758), Coccinella septempunctata Linnaeus, 1758, Coccinella undecimpunctata Linnaeus, 1758, Exochomus undulates Weise, 1878, Hippodamia variegate (Goeze, 1777), Hippodamia tredecimpunctata (Linnaeus, 1758), Oenopia conglobata (Linnaeus, 1758), Oenopia oncina (Olivier, 1808), Propylea quatuordecimpuctata (Linnaeus, 1758), Psyllobora vigintiduopunctata (Linnaeus, 1758), Scymnus syriacus (Marseul, 1868), Scymnus mongolicus (Weise, 1890).
\end{abstract}

KEY WORDS: Aphis punicae, lady beetles, Najafabad, natural enemies, pomegranate

(Article chronicle: Received: 10-01-2016; Revised: 05-02-2016; Accepted: 03-03-2016)

\section{INTRODUCTION}

Pomegranate (Punica granatum L.), is one of ancient fruit trees. The pomegranate fruit juice makes an excellent drink which contains potassium, phosphorous and calcium as well as micronutrients. The antioxidant, immune-boosting, and anti-carcinogenic properties of the pomegranate offers its multiple potential medical applications (Kaplan et al., 2001). Iran as a center of pomegranate growth possesses more than 800 genotypes which have been collected and maintained in Yazd and Saveh germplasm (BehzadiShahrebabaki, 1998).

The pomegranate tree is attacked by several insect species which decrease the quality and quantity of its product. Aphids are among the most serious and widespread pests in pomegranate orchards (Rouhani et al., 2013). This species is well known for its ability to reduce plant vigor, facilitate the growth of mold on leaves, and consequently reduces crop quality and yield. Both adults and nymphs feed on leaves, inflorescences and fruits (Moawad and AlBarty, 2011). The species has a high reproductive capacity so extensive use of insecticide to control it results in the development of resistance (Pavela et al., 2009). From the years ago, the association between the predatory behaviors of Coccinellidae with many pests e.g. whitefly, mealy bugs, scales, mites and especially aphids was recognized (Obrycki and Kring, 1998). Knowledge of these useful enemies is necessary for any integrated pest management program on the pests in crops and orchards.

Cultivation of pomegranate in Najafabad region in Isfahan province, Iran has a long history. So, the objective of this study was to investigate the lady beetles fauna on pomegranate trees as the natural enemies of Aphis punicae in Najafabad region, western part of Isfahan province. 


\section{MATERIAL AND METHODS}

The samples of lady beetles were collected from the 3 orchards of pomegranate at different locations (South, west and north) in Najafabad region, Isfahan province, Iran. Each orchard was repeatedly sampled in March to September, 2014. Collecting the adult specimens were carried out with a standard sweeping net and a handheld aspirator. Adult insects collected from various orchards were preserved in $70 \%$ ethyl alcohol in bottles. Each bottle was labeled with information of site and date of collection. The morphological characters of each species were carefully studied under stereomicroscope. The lady beetles were identified to the species level with the help of available keys (Gordon, 1985; Gordon, 1990; Fürsch, 1981; Fürsch, 1989). The identified specimens were confirmed by Dr. M. R. Bagheri from Agriculture and Natural Resources Research Center of Isfahan Province, Iran.

\section{RESULTS AND DISCUSSION}

Overall, 12 species belonging to eight genera from four tribes and three subfamilies were recorded on the pomegranate trees from Najafabad region in Isfahan province.

\section{Subfamily Coccinellinae}

\section{Tribe Coccinellini Latreille, 1807}

Adalia bipunctata (Linnaeus, 1758): Length 3.7 to $5.1 \mathrm{~mm}$, width 2.8 to $3.9 \mathrm{~mm}$, dorsal color pattern highly variable genitalia with parameres less than basal lobe; siphon spoon-shaped apically (Gordon 1985). The 2-spotted ladybird $A$. bipunctata occurred abundantly in the sampling locations. Four different separable color pattern morphs of $A$. bipunctata was observed and identified. 1) Pale red, separated 2 eyed black-spotted: The wing case with 2 pale red backgrounds and there is a single eyed black spot in the middle of each elytron. Pronotum white with black spots, a bold black m-mark (Fig. 1-A). 2) Pale red, separated 14 black-spotted: The wing case has the pale red background and there are 7 black spots on each wing case. The first and second black marking is on the down of wing, third, fourth and fifth are in the middle of wing and sixth and seventh are in the top of wing. Pronotum white with black spots, a black m-mark (Fig. 1-A1). 3) White separated 20 blackspotted: The wing case has a white background and there are 10 black spots on each wing case. Pronotum white with black spots, a black m-mark (Fig. 1-A2). 4) Black separated 4 red-spotted: The wing case has a black background with 2 red spots on each wing case. Legs and underside of the abdomen are black and each elytron has two red markings. The first red marking is at the forward angle and second is central of elytron (Fig. 1-A3).

Coccinella septempunctata Linnaeus, 1758: Length 5.3 to $7.6 \mathrm{~mm}$, width 4 to $5.1 \mathrm{~mm}$ (Fig. 1-C), elytra red with 6 black spots in addition to scutellar spot, prosternal keels diverging to the front (Gordon 1985).

Coccinella undecimpunctata Linnaeus, 1758: Length 3.5 to $5 \mathrm{~mm}$, width 3.2 to $4 \mathrm{~mm}$ (Fig. 1-B), elytra red with 10 black spots in addition to scutellar spot, pronotum with anterior margin black at middle, ventral pale spot large, prosternal keels parallel to the front (Gordon 1985).

Hippodamia tredecimpunctata (Linnaeus, 1758): Length 3.30 to $3.50 \mathrm{~mm}$, width 3.80 to $4 \mathrm{~mm}$ in size with nearly rounded (Fig. 1-F), 11 spots always in two rows approximately parallel to the edge of the elytra (13-spots), the white border at the sides of the pronotum (Gordon 1985).

Hippodamia variegata (Goeze, 1777): Length 4.4 to $5 \mathrm{~mm}$, width 3 to $3.25 \mathrm{~mm}$ (Fig. 1-E), color and pattern of the elytra varied, male genitalia with flat trabes, fovea at apex; sipho with membranous process at apex. In the collected samples of this species, elytra were red with 6 black spots in addition to scutellar spot. This predator was the most abundant coccinellid predator in three sites (Iablokoff-khnzorian 1982).

Oenopia conglobata (Linnaeus, 1758): Length 3.3 to $4 \mathrm{~mm}$, width 2.4 to $3 \mathrm{~mm}$ (Fig. 1-G), male genitalia with triangular sipho at apex. Female genitalia with apically divided basal lobe. Coloration of elytra in this species was pink with 8 black spots (Iablokoff-khnzorian, 1982).

Oenopia oncina (Olivier, 1808): Length 3.3 to $4 \mathrm{~mm}$, width 2.4 to $3 \mathrm{~mm}$, male genitalia with flat sipho and long setae at apex, female genitalia with basal lobe not apically divided (Iablokoff-khnzorian 1982). Two form of this species was collected. 1) The background of the elytra in most specimens was black with joining yellow spots (Fig. 1-H). 2) The background of the elytra was black with joining yellow spots, two spots are in the middle and down on each wing (Fig. 1-H1). 


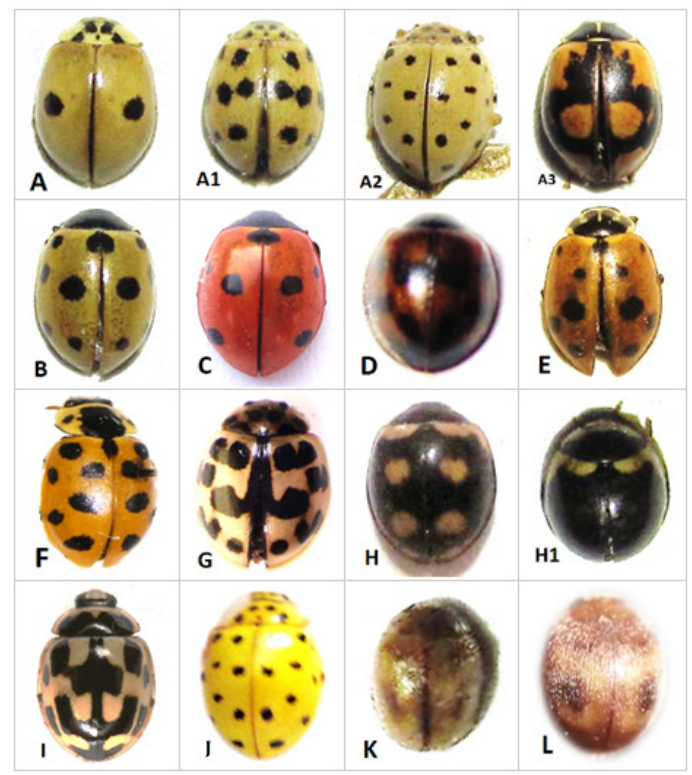

Fig. 1. A, A1, A2 and A3: Adalia bipunctata (This species has polymorphism in form); B: Coccinella undecimpunctata; C: Coccinella septempunctata; D: Exochomus undulates; E: Hippodamia variegate; F: Hippodamia tredecimpunctata; G: Oenopia conglobate; Hand H1: Oenopia oncina (This species has polymorphism in form); I: Propylea quatuordecimpuctata; J: Psyllobora vigintiduopunctata; K: Scymnus mongolicus; L: Scymnus syriacus.

Propylea quatuordecimpunctata (Linnaeus, 1758): Length 3 to $3.5 \mathrm{~mm}$, width 4.6 to $5.2 \mathrm{~mm}$ (Fig. 1-I), pale pink elytra (wing covers) with rectangular black spots, elytra usually with 14 black spots, but may be fused together near midline, pronotum (hard shell behind head) black with pale anterior and lateral border (Gordon 1985).

\section{Tribe Psylloborini Casey, 1899}

Psyllobora vigintiduopunctata (Linnaeus, 1758): Length 1.75 to $3.0 \mathrm{~mm}$ (Fig. 1-J), width 1.40 to $2.35 \mathrm{~mm}$, pronotum with 4 dark spots; elytra usually with 22 spots, spots partially confluent, pattern variable. The background color was yellow; the color of the markings was black (Gordon 1985).

\section{Subfamily Chiolocorinae}

\section{Tribe Chilocorini Mulsant, 1846}

Exochomus undulatus Weise, 1878: Length 3 to 4.2 $\mathrm{mm}$, width 2.4 to $3.6 \mathrm{~mm}$ (Fig. 1-D), and elytra black with orange and checkered-shape maculation, spots sometimes joined. Male genitalia with parameres slightly shorter than basal lobe; sipho membranous at apex. Female genitalia with a long sperm duct, genital plate elongated (Gordon 1985).

\section{Subfamily Scymninae}

\section{Tribe Scymnini Weise, 1846}

Scymnus (Pullus) mongolicus (Weise, 1890): Length 1.5 to $2.3 \mathrm{~mm}$, width 1 to $1.5 \mathrm{~mm}$ (Fig. 1-K), elytra in the middle almost hairless and consecutive which here as polished shiny, pronotum very dense, elytra punctured stronger and less dense, black head, elytra same if bright red, at the seam with a wide black stripe, which extends up behind the center and then suddenly at an acute angle is narrowed; also the side edge in the mid blackish (Fürsch 1989).

Scymnus (Pullus) syriacus (Marsuel, 1868): Length 1.7 to $2.3 \mathrm{~mm}$, width 1.2 to $1.6 \mathrm{~mm}$ (Fig. 1-L), elytra light to dark brown with 1 cycle shape spot on middle with yellow surroundings, dorsal surface with bright pubescence, postcoxal line on 1st abdominal sternum complete, recurred, extending to base of first sternum. Male genitalia with parameres as long as basal lobe; sipho curved and with process at apex, with 1 membranous lobe near the apical (Fürsch 1989).

The present study was the first attempt to explore, identify and describe the coccinellid fauna associated with Aphis punicae on the pomegranate trees of the Najafabad region, which will be helpful for the future researches on the biological control of this aphid. Similar faunistic studies were carried out by other workers in Iran. For example, Mehrnejad et al. (2011) reported 17 coccinellid species, at the wild pistachio plantation and 11 species from planted pistachio trees in Rafsanjan. Mohammadpoor et al. (2013) reported also 12 species from 11 genera, 4 tribes and 3 subfamilies from Lorestan province. This study revealed the coccinellid community structure in the three orchards of pomegranate, more or less in different conditions. Overall, 12 species from 8 genera belonging to subfamilies Coccinellinae, Chilororinae and Scymninae exist in the region. The indentified species were Adalia bipunctata, Coccinella undecimpunctata, Coccinella septempunctata, Exochomus undulates, Hippodamia variegate, Hippodamia tredecimpunctata, Oenopia conglobate, Oenopia oncina, Propylea quatuordecimpuctata, Psyllobora vigintiduopunctata, Scymnus mongolicus and Scymnus syriacus. 


\section{REFERENCES}

Behzadi Shahrbabaki H. 1998. Genetic diversity of pomegranate genotypes in Iran. Nashr Amoozesh Keshavarzi, Tehran, Iran. p. 265.

Fursch H. 1989. The Arabian species of the Scymnus (Pullus) guimeti-group (Coleoptera, Coccinellidae). Fauna of Saudi Arabia. 10: 113-122.

Fursch H. 1981. Eine neue Nephus - Art aus Iran (Coleoptera, Coccinellidae). Kundid. p. 137-139.

Gordon RD. 1985. The Coccinellidae (Coleoptera) of America North of Mexico. 93: 1-912.

Gordon RD. 1990. The Coccinellidae (Coleoptera) of Bermuda. J N Y Entomol Soc. 8(3): 265-309.

Iablokoff-Khnzorian SM. 1982. Coccinellidae of the tribe Epilachnini (Coleoptera, Coccinellidae) of the USSR. I. Entomologischeskoe obozrenie 59: 292-310. English Translation in Entomological Review 59: 46-58.

Kaplan M, Hayek T, Raz A, Coleman R, Dornfeld L, Vaya J, Aviram M. 2001. Pomegranate juice supplementation to atherosclerotic mice reduces macrophage lipid peroxidation, cellular cholesterol accumulation and development of atherosclerosis. J Nutr. 131(8): 20822089.

Moawad SS, Al-Barty AMF. 2011. Evaluation of some medicinal and ornamental plant extracts toward pomegranate aphid, Aphis punicae (Passerini) under laboratory conditions. Afr J Agric Res. 6(10): 24252429.

Mohammadpoor A, Jafari R, Karahrudi ZR. 2013. The faunistic survey of predatory lady beetles (Coleoptera, Coccinellidae) in the Aleshtar region (Lorestan province) Iran. Intl. J Agri Crop Sci. 6(11): 723-728.

Obrycki JJ, Kring TJ. 1998. Predaceous Coccinellidae in biological control. Ann Rev Entomol. 43(1): 295-321.

Obrycki JJ, Harwood JD, Kring TJ, O'Neil RJ. 2009. Aphidophagy by Coccinellidae: application of biological control in agroecosystems. Biol Control 51(2): 244-254.

Pavela R, Nadezda V, Bozena S. 2009. Repellency and toxicity of three Impatiens species (Balsaminaceae) extracts on Myzus persicae Sulzer (Homoptera: Aphididae). J Biopesticides 2(1): 48-51.

Rouhani M, Samih MA, Izadi H, Mohammadi E. 2013. Toxicity of new insecticides against pomegranate aphid, Aphis punicae. Intl Res J Appl Basic Sci. 4(3): 496-501.

Salehi T, Pashaei Rad SH, Mehrnejad MR, Shokri MR. 2011. Ladybirds associated with pistachio trees in part of Kerman province, Iran (Coleoptera: Coccinellidae). Iran J Anim Biosyst. 7(2): 157-169. 